ISSN: 1410-8917

Jurnal Kimia

-Sains \&

Aplikasi
Jurnal Kimia Sains dan Aplikasi Journal of Scientific and Applied Chemistry

Journal homepage: http://ejournal.undip.ac.id/index.php/ksa

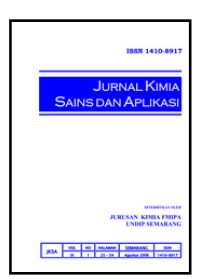

\title{
Isolasi, Identifikasi dan Uji Aktivitas Senyawa Triterpenoid Rimpang Bengle (Zingiber cassumunar Roxb.) sebagai Antibakteri
}

\author{
Afrezza Lukman Rosyid ${ }^{\mathrm{a}}$, Enny Fachriyah ${ }^{\mathrm{a}^{*}}$, Dewi Kusrini ${ }^{\mathrm{a}}$ \\ a Organic Chemistry Laboratory, Chemistry Department, Faculty of Sciences and Mathematics, Diponegoro University, Jalan Prof. \\ Soedarto, Tembalang, Semarang \\ * Corresponding author: enny.fachriyah@live.undip.ac.id
}

Article Info

Keywords:

isolation, Zingiber cassumunar Roxb,

triterpenoids,

Liebermann-

Burchard,

antibacterial

\section{Abstract}

Research on the isolation, identification and test activity of triterpenoid compound rhizome bengle (Zingiber cassumunar Roxb) as antibacterial has been conducted. The aim of this research is to get triterpenoid group compound from bengle rhizome and to know its activity against E.coli and S.aureus bacteria. The stages of this study included the extraction using $96 \%$ ethanol and then partitioned with $n$-hexane. The concentrated n-hexane extract was then subjected to column chromatography. The identification of positive column fractions containing triterpenoids was performed using LiebermannBurchard reagents. The triterpenoid positive fraction was further separated by the preparative chromatography method. The obtained isolates were then tested for purity using various TLC methods and two-dimensional TLC. Isolates were also analyzed using FT-IR and KG-SM. The result of FT-IR analysis showed that the isolate has vibration at wave number $2924 \mathrm{~cm}^{-1}$ which is asymmetric $\mathrm{CH}$ as vibration stretching, $2862 \mathrm{~cm}^{-1}$ vibration $\mathrm{CH}$ symmetry, $1720 \mathrm{~cm}^{-1}$ vibration $\mathrm{C}=0,1465 \mathrm{~cm}^{-1}$ bending vibration $\mathrm{CH}$ of $\mathrm{CH} 2,1395 \mathrm{~cm}^{-1}$ is the vibration of the gem-dimethyl group. The results of the KG-SM analysis showed that the isolates had a retention time of 24.5 minutes, the molecular weight of 426 , with the base peak of $\mathrm{m} / \mathrm{z} 69$. Based on the isolate database is a friedelen3-o compound.

\section{Abstrak}

Penelitian mengenai isolasi, identifikasi dan uji aktivitas senyawa triterpenoid rimpang bengle (Zingiber cassumunar Roxb) sebagai antibakteri telah dilakukan. Penelitian ini bertujuan untuk mendapatkan senyawa golongan triterpenoid dari rimpang bengle serta mengetahui aktivitasnya terhadap bakteri E.coli dan S.aureus. Tahapan penelitian ini meliputi ekstraksi menggunakan etanol $96 \%$ dan kemudian dipartisi dengan nheksana. Ekstrak n-heksana yang telah dipekatkan kemudian dilakukan kromatografi kolom. Identifikasi fraksi kolom yang positif mengandung triterpenoid dilakukan dengan menggunakan pereaksi Liebermann-Burchard. Fraksi positif triterpenoid selanjutnya dipisahkan melalui metode kromatografi preparatif. Isolat yang didapat selanjutnya diuji kemurnian menggunakan metode KLT berbagai eluen dan KLT dua dimensi. Isolat juga dianalisis menggunakan FT-IR dan KG-SM. Hasil analisis FT-IR menunjukkan isolat memiliki vibrasi pada bilangan gelombang $2924 \mathrm{~cm}^{-1}$ yang merupakan vibrasi ulur $\mathrm{C}-\mathrm{H}$ asimetri, $2862 \mathrm{~cm}^{-1}$ vibrasi ulur $\mathrm{C}-\mathrm{H}$ simetri, $1720 \mathrm{~cm}^{-1}$ vibrasi ulur $\mathrm{C}=\mathrm{O}, 1465 \mathrm{~cm}^{-1}$ vibrasi tekuk $\mathrm{C}-\mathrm{H}$ dari $\mathrm{CH} 2,1395 \mathrm{~cm}^{-1}$ adalah vibrasi gugus gem-dimetil. Hasil analisis KG-SM menunjukkan isolat memiliki waktu retensi 24,5 menit, bobot molekul 426, dengan puncak dasar $\mathrm{m} / \mathrm{z}$ 69. Berdasarkan database isolat merupakan senyawa friedelen-3-o. 


\section{Pendahuluan}

Indonesia merupakan negara kepulauan yang sangat luas, mempunyai kurang lebih 35.000 pulau yang besar dan kecil dengan keanekaragaman jenis flora dan fauna. Indonesia diperkirakan mempunyai 100 sampai 150 famili tumbuh-tumbuhan, dan dari jumlah tersebut sebagian besar mempunyai potensi untuk dimanfaatkan sebagai tanaman industri, tanaman buah-buahan, tanaman rempah-rempah dan tanaman obat-obatan [1]. Wilayah Nusantara memiliki 40.000 spesies tanaman dan 940 diantaranya memiliki khasiat obat. Indonesia merupakan salah satu negara penghasil tanaman obat terbesar di dunia.

Salah satu tanaman obat yang banyak terdapat di Indonesia adalah bengle (Zingiber cassumunar Roxb.). Sebanyak 300 ton per bulan bengle dihasilkan hanya dari wilayah Jawa Tengah. Bagian tanaman bengle yang sering digunakan adalah rimpangnya. Rimpang bengle selama ini digunakan sebagai obat sembelit, sakit kuning, demam, sakit kepala, perut nyeri, masuk angin, rematik, asma, serta mengatasi peradangan [2]. Kandungan yang terdapat dalam rimpang bengle adalah flavonoid, tanin, saponin, dan triterpenoid. Selain itu juga terdapat senyawa asam organik, mineral, lemak, gom, albuminoit, gula, damar, serta minyak atsiri.

Triterpenoid merupakan golongan senyawa metabolit sekunder. Golongan senyawa triterpenoid mempunyai nilai ekologi bagi tumbuhan karena senyawa ini bekerja sebagai antifungi [3], insektisida, antivirus [4],antioksidan [5] dan antibakteri [6]. Kajian terhadap terpenoid pada rimpang bengle yang telah dilakukan salah satunya dilakukan oleh Heny Prihartini pada tahun 2000 yang sudah berhasil mengisolasi Seskuiterpena pada Fraksi Etil Asetat dari Rimpang Bengle. Mengingat bengle merupakan tanaman yang digunakan sebagai obat tradisional dan secara kualitatif mengandung triterpenoid, maka perlu dilakukan isolasi, identifikasi dan uji aktivitas antibakteri triterpenoid dari rimpang bengle (Zingiber cassumunar Roxb).

\section{Metode Penelitian}

Preparasi sampel.

Rimpang bengle (Zingiber cassumunar Roxb.) berasal dari Balai Penelitian Tanaman Obat (BPTO) Tawangmangu, Jawa Tengah. Sampel dicuci, diiris tipis kemudian dikeringkan dengan cara diangin-anginkan, sampel kemudian digiling, sehingga diperoleh serbuk rimpang bengle.

Uji Skrinning.

Uji skrinning terhadap rimpang bengle meliputi uji alkaloid, saponin, flavonoid, tanin, kuinon, triterpenoid.

\section{Uji Alkaloid.}

Sebanyak $5 \mathrm{~g}$ serbuk rimpang bangle diletakkan pada kurs porselen dan dilembabkan dengan $5 \mathrm{~mL}$ ammonia $25 \%$, digerus dan ditambahkan dengan $20 \mathrm{~mL}$ kloroform kemudian disaring. Sebanyak $10 \mathrm{~mL}$ filtrat diekstraksi dengan $\mathrm{HCl}$ (1:10) sebanyak 2 kali. Sebanyak
$5 \mathrm{~mL}$ larutan ini dimasukkan dalam tabung reaksi. Adanya alkaloid ditunjukkan dengan terbentuknya endapan putih pada larutan setelah penambahan pereaksi Mayer.

\section{Uji Saponin.}

Sebanyak $5 \mathrm{~g}$ serbuk rimpang bangle dididihkan dalam $100 \mathrm{~mL}$ aquades dan disaring dalam keadaan panas. Sebanyak $10 \mathrm{~mL}$ filtrat ditampung dalam tabung reaksi, dikocok kuat secara vertikal dan ditambahkan HCl. Adanya saponin ditunjukkan dengan timbulnya busa yang tetap stabil dalam larutan setelah penambahan $\mathrm{HCl}$

\section{Uji Flavonoid.}

Sebanyak $5 \mathrm{~g}$ serbuk rimpang bangle dididihkan dalam $100 \mathrm{~mL}$ aquades, didinginkan, dan disaring. Sebanyak $5 \mathrm{~mL}$ filtrat ditambahkan serbuk Magnesium, $1 \mathrm{~mL} \mathrm{HCl}$, dan $2 \mathrm{~mL}$ amilalkohol, dikocok kuat-kuat dan dibiarkan memisah. Adanya flavonod ditunjukkan jika terbentuk warna merah, kuning, atau jingga pada lapisan amilalkohol.

\section{Uji Tanin.}

Sebanyak $10 \mathrm{~g}$ serbuk rimpang bangle dididihkan dalam $100 \mathrm{~mL}$ aquades, didinginkan, kemudian disaring. Filtrat yang diperoleh ditambahkan dengan larutan $\mathrm{FeCl}_{3} 1 \%$. Terbentuknya larutan berwarna coklat kehitaman menunjukkan adanya tannin.

\section{Uji Steroid/Triterpenoid.}

Sebanyak $5 \mathrm{~g}$ serbuk rimpang bangle dimaserasi dengan $20 \mathrm{~mL}$ eter selama 2 jam dan disaring. Sebanyak $5 \mathrm{~mL}$ filtrat diuapkan hingga kering dan ditambahkan dengan pereaksi Lieberman-Burchard yaitu 2 tetes anhidrida asam asetat dan 1 tetes $\mathrm{H}_{2} \mathrm{SO}_{4}$. Terbentuknya warna biru/ merah menunjukkan adanya senyawa steroid/ triterpenoid.

\section{Maserasi.}

Maserasi dilakukan dengan perendaman menggunakan etanol 96\%. Serbuk rimpang bengle sebanyak $1070 \mathrm{~g}$ dimaserasi ke dalam etanol sebanyak 4 liter. Pelarut etanol tersebut diganti selama 24 jam sekali selama 1 minggu. Ekstrak etanol kemudian dipekatkan menggunakan rotary evaporator untuk mendapatkan ekstrak kental etanol. Tahap selanjutnya adalah partisi ekstrak kental etanol dengan menggunakan $n$-heksana pada perbandingan 1:1 untuk diambil fraksi n-heksana yang bersifat non-polar. Fraksi n-heksana selanjutnya dipekatkan dengan rotary evaporator sehingga diperoleh fraksi kental n-heksana.

\section{Pemisahan}

Fraksi n-heksana selanjutnya dikromatografi lapis tipis dengan menggunakan silika gel dengan berbagai eluen hingga didapatkan eluen yang dapat memisahkan ekstrak tersebut dengan bagus. Setelah didapatkan eluen yang sesuai selanjutnya dilakukan kromatografi kolom dengan eluen tersebut. Dari hasil kromatografi kolom tersebut didapatkan beberapa vial, selanjutnya vial-vial tersebut dikromatografi lapis tipis untuk 
menentukan fraksi besar dari masing-masing vial tersebut. Fraksi besar dapat dikelompokkan berdasarkan pola noda KLT yang sama. Selanjutnya dari fraksi-fraksi tersebut dilakukan uji Libermann-Burchard untuk menentukan adanya triterpenoid.

\section{KLT Preparatif.}

Fraksi yang positif mengandung triterpenoid selanjutnya dilakukan pemisahan lebih lanjut. Kromatografi preparatif dilakukan dengan menggunakan fase diam silika gel 60 GF254 ketebalan 1 mm dengan fase gerak kloroform: n-heksana (7:5).

Uji kemurnian.

solat hasil pemisahan kromatografi preparatif kemudian diuji kemurniannya dengan metode KLT berbagai eluen dan KLT dua dimensi. Uji kemurnian dilakukan pada plat KLT menggunakan eluen etil asetat : n-heksana (1:1), aseton : n-heksana (1:1), metanol : kloroform (1:1), n-butanol, dan n-heksana : metanol (1:1). Metode KLT dua dimensi diakukan pada plat KLT berukuran $10 \mathrm{~cm} \times 10 \mathrm{~cm}$ dengan menggunakan eluen metanol : klorofom (1:1) dan aseton : n-heksana (1:1).

\section{Analisis FT-IR dan KG-SM.}

Isolat murni dianalisis menggunakan FT-IR bertujuan untuk mengetahui gugus fungsi apa saja yang terdapat dalam isolat murni tersebut. KG-SM digunakan untuk mengetahui bobot molekul serta pola fragmentasi dari isolat murni yang didapat.

\section{Uji antibakteri.}

Pelaksanaan uji aktivitas antibakteri ini dilakukan dengan metode difusi cakram. Isolat triterpenoid rimpang bengle diuji pada konsentrasi $10 \%, 7 \%, 5 \%$, dan 3\% terhadap pertumbuhan bakteri. Nutrien Agar yang telah dibuat kemudian disterilisasi dalam autoklaf selama 24 jam. Cawan petri yang berisi media Nutrien Agar yang telah disterilisasi dan memadat diberi supensi bakteri dan diratakan dengan menggunakan jarum ose. Setelah itu cakram kertas dengan diameter tertentu yang telah dicelupkan ke dalam ekstrak rimpang bengle masing-masing dengan konsentrasi yang berbeda diletakan pada permukaan media NA yang telah diinokulasikan bakteri. Cawan petri diinkubasi selama 24 jam pada suhu 370C. Populasi mikroba yang digunakan adalah 1x108 CFU/ml.

\section{Hasil Dan Pembahasan}

\section{Preparasi sampel dan Uji Skrinning}

Pada penapisan fitokimia didapatkan bahwa serbuk rimpang bengle mengandung senyawa flavonoid, saponin, tannin, dan triterpenoid.

\section{Maserasi}

Metode maserasi dipilih karena memiliki kelebihan antara lain sederhana, relatif murah, tidak memerlukan peralatan yang rumit, dan dapat menghindari kerusakan komponen senyawa yang tidak tahan panas karena metode ini dilakukan tanpa proses pemanasan. Maserasi dengan pelarut etanol berfungsi untuk mengambil senyawa metabolit sekunder dalam rimpang bengle. Ekstrak etanol hasil maserasi didapatkan cairan berwarna coklat kehitaman. Selanjutnya dipekatkan dengan menggunakan rotary evaporator sehingga didapatkan $150 \mathrm{ml}$ ekstrak etanol rimpang bengle.

Ekstrak etanol pekat selanjutnya dipartisi dengan menggunakan pelarut $n$-heksana yang berfungsi untuk memisahkan senyawa non polar dengan senyawa polar lainnya. Triterpenoid merupakan senyawa non polar dan dapat larut dalam n-heksana. Partisi dilakukan dengan perbandingan 1:1 sampai tidak ada lagi bagian non polar dari ekstrak etanol tersebut yang tersisa, ditandai dengan warna fraksi $n$-heksana tetap jernih ketika dilakukan ekstraksi. Setelah didapatkan fraksi nheksana selanjutnya dipekatkan menggunakan rotary evaporator, sehingga didapatkan fraksi kental nheksana sebanyak 7 gram.

\section{Pemisahan}

Fraksi kental n-heksana yang didapat kemudian dipisahkan dengan kromatografi kolom. Eluen yang digunakan dalam kromatografi kolom adalah kloroform:n-heksana (11:9). Ekstrak kental yang digunakan sebanyak 2 gram. Kromatografi kolom menghasilkan 220 vial. Uji KLT yang dilakukan menunjukkan terdapat 5 fraksi besar A, B, C, D, dan E, fraksi yang positif mengandung triterpenoid adalah fraksi D.

Fraksi D yang positif mengandung triterpenoid kemudian dilanjutkan pemisahannya untuk mendapatkan isolat triterpenoid dengan metode kromatografi preparatif. Eluen yang digunakan dalam kromatografi preparatif yaitu kloroform:n-heksana (7:5). Gambar kromatografi prepatifnya sebagai berikut:

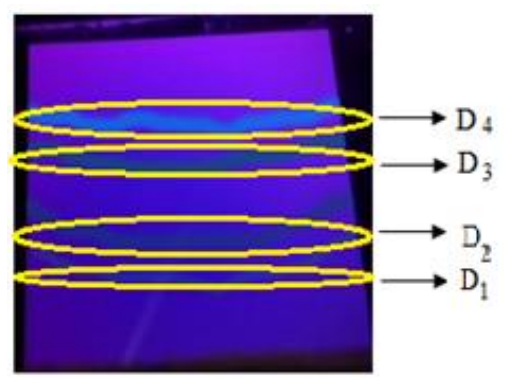

Gambar 1. Hasil kromatografi preparatif fraksi D menggunakan eluen kloroform:n-heksana (7:5)

Pita yang positif mengandung triterpenoid adalah pita D3. Tahap selanjutnya pita D3 kemudian dikerok untuk mendapatkan isolat murni, dan dilakukan KLT kembali untuk mengetahui apakah hasil dari kromatografi preparatif sudah murni. Kemurnian ditunjukkan dengan adanya noda tunggal pada saat diuji. Namun ternyata masih terdapat dua noda yang terdeteksi, sehingga perlu dilakukan KLT preparatif kembali untuk mendapatkan noda tunggal. Kromatografi preparatif D3 masih menunjukkan adanya dua pita, yang positif triterpenoid adalah D3A. Berikut adalah gambar kromatografi preparatif yang kedua: 


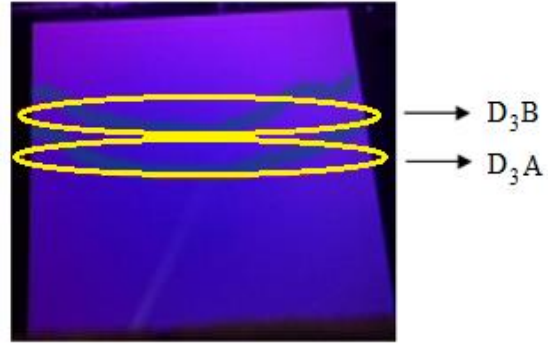

Gambar 2. Hasil kromatografi preparatif fraksi D3 menggunakan eluen kloroform:n-heksana (7:5)

\section{Uji Kemurnian}

Setelah dilakukan kromatografi preparatif kedua, pita D3A dikerok lalu direndam menggunakan nheksana pro analis. Pelarut $\mathrm{n}$-heksana akan melarutkan isolat triterpenoid yang diperoleh, selanjutnya diuji kemurniannya menggunakan KLT dengan berbagai eluen. Dari hasil KLT berbagai eluen, didapatkan satu noda yang membuktikan bahwa isolat yang didapatkan merupakan isolat murni. Gambar hasil uji kemurnian dengan berbagai eluen adalah sebagai berikut:

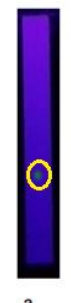

a

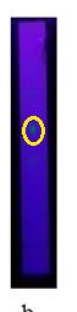

b
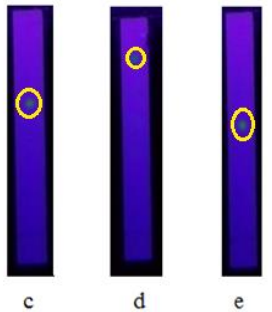

Gambar 3. Hasil uji kemurnian isolat menggunakan KLT berbagai eluen: a. etil asetat: $n$-heksan (1:1); $b$. aseton:n-heksan (1:1); c. metanol:kloroform (1:1) d. nbutanol; e. n-heksan:metanol (1:1)

Uji kemurnian dilanjutkan menggunakan KLT dua dimensi. Proses analisis dengan KLT dua dimensi menggunakan eluen yang berbeda pada elusi pertama dan kedua. Elusi pertama dilakukan menggunakan eluen metanol : kloroform (1:1). Setelah elusi pertama selesai maka plat KLT kemudian dikeringkan lalu diputar 900 kemudian dielusi kembali menggunakan eluen aseton : n-heksan (1:1). Hasil analisis menggunakan KLT dua dimensi ditunjukkan pada gambar berikut:

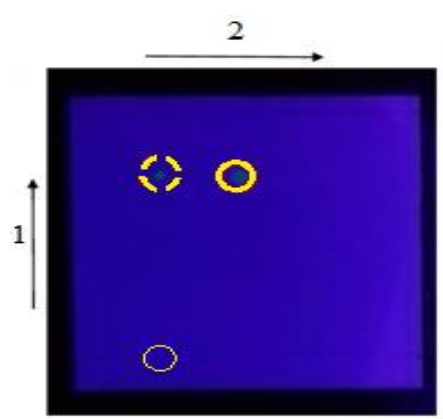

Gambar 4. Hasil uji kemurnian isolat menggunakan KLT dua dimensi

\section{Analisis FT-IR dan KG-SM}

Isolat triterpenoid murni dikarakterisasi dengan spektrofotometer FTIR untuk menunjukkan adanya beberapa gugus fungsi, spektra inframerah dapat dilihat pada gambar berikut:

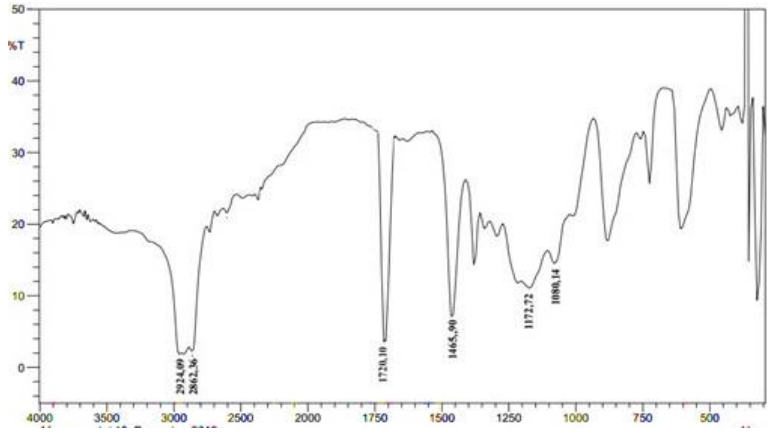

Gambar 5. Spektrum FTIR isolat triterpenoid rimpang bengle

Hasil FTIR terhadap isolat menunjukkan adanya serapan pada bilangan gelombang $2924 \mathrm{~cm}^{-1}$ yang merupakan serapan vibrasi ulur ikatan $\mathrm{C}-\mathrm{H}$ asimetri. Serapan pada bilangan gelombang $2862 \mathrm{~cm}^{-1}$ adalah vibrasi ulur ikatan $\mathrm{C}-\mathrm{H}$ simetri. Bilangan gelombang $1720 \mathrm{~cm}^{-1}$ menunjukkan adanya gugus karbonil $(\mathrm{C}=0)$. Vibrasi yang muncul pada daerah bilangan gelombang $1465 \mathrm{~cm}^{-1}$ menunjukkan adanya serapan tekuk dari gugus fungsi $\mathrm{CH} 2$. Vibrasi yang terjadi pada daerah bilangan gelombang $1395 \mathrm{~cm}^{-1}$ merupakan vibrasi tekuk dari gugus fungsi gem-dimetil. Analisis sementara dari hasil spektrum inframerah diduga isolat memiliki rantai karbon yang memiliki gugus gem-dimetil dan gugus keton pada kerangkanya.

Analisis selanjutnya yang dilakukan adalah dengan menggunakan KG-SM. Hasil analisis dengan KG seperti yang terlihat pada gambar berikut:

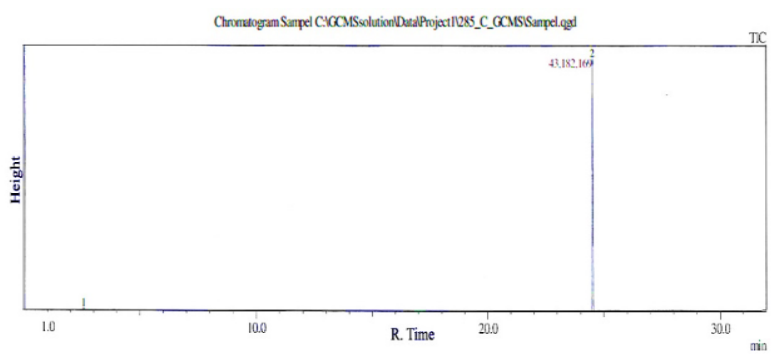

Gambar 6. Kromatogram isolat triterpenoid rimpang bengle 
<Target >

Line:2 R.Time:24,530(Scant:481) MassPeaks:426

Raw Mode:Averaged $24,430-24,646(425-427)$ BasePeaks:69,10(824403-4) BG Mode:Calc. from Peak Group 1 - Event 1

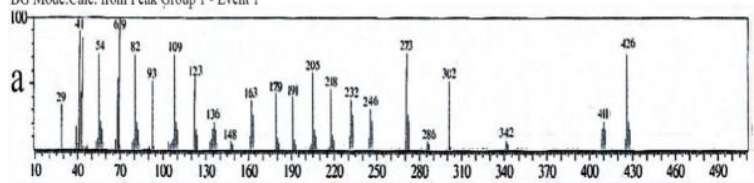

Hitt1 Entry: 3577 Library: WILEY7.LIB

SI:96 Formula:C30 H50 O CAS: 559-74-0 MolWeight: 426 Retindex:0

CompoundName: friedelin SSd:a-friedooleanan-3-oneSS

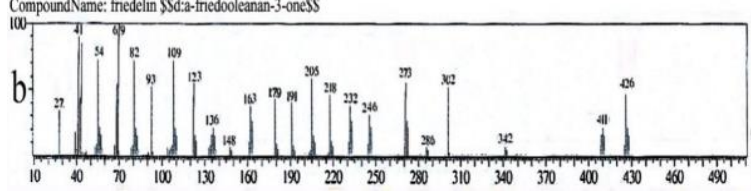

Gambar 7. Spektogram MS (a) isolat triterpenoid rimpang bengle (b) friedelen-3-on (database)

Berdasarkan kromatogram di atas dapat dilihat muncul satu puncak yang memiliki waktu retensi 24,5 menit. Kromatogram yang hanya memunculkan satu puncak saja, dapat dikatakan isolat telah murni. Selanjutnya untuk mengetahui berat molekul dari isolat senyawa hasil analisis kita dapat ketahui dari spektrogram MS. Spektrogram SM dari isolat dan spektrogram senyawa friedelen-3-on dari database pada gambar 7 .

Berdasarkan spektogram yang dihasilkan, dapat diketahui isolat memiliki berat molekul sebesar $\mathrm{m} / \mathrm{z} 426$ dan puncak dasarnya adalah $\mathrm{m} / \mathrm{z}$ 69. Spektrogram menunjukkan nilai $\mathrm{m} / \mathrm{z}$ sebesar $426,411,302,273,246$, 232, 218, 205, 191, 179, 163, 123, 109, 93, 82, 69, 54, 41, 29. Spektogram isolat kemudian dibandingkan dengan spektogram database yang memiliki Similarity Index (SI) 96 yaitu senyawa friedelen-3-on. Spektogram antara senyawa isolat dan senyawa dari database menunjukkan berat molekul dan pola fragmentasi yang sama, yang artinya diduga bahwa senyawa isolat dan senyawa dari database identik. Senyawa hasil isolasi diduga adalah friedelen-3-on. Struktur senyawa dari friedelen-3-on berdasarkan SDBS (Spectral Database for Organic Compound) pada gambar 8.

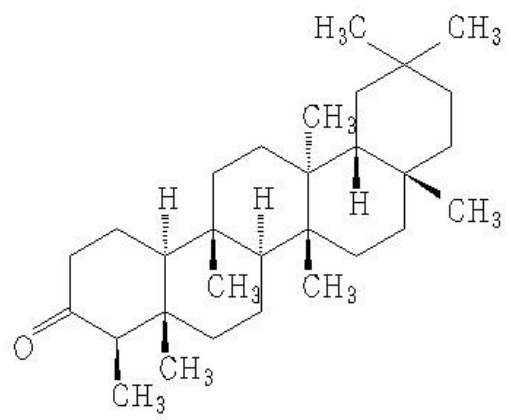

Gambar 8. Struktur Friedelen-3-on

\section{Uji Antibakteri}

Uji antibakteri isolat triterpenoid dilakukan terhadap bakteri Eschercia coli dan Staphilococcus aureus. Eschercia coli mewakili gram negatif dan Staphylococcus aureus mewakili gram positif. Isolat triterpenoid yang didapatkan sebanyak 0,03 gram kemudian dilarutkan ke dalam $3 \mathrm{~mL}$ aquades dengan ditambahkan 2 tetes DMSO.
Penambahan DMSO berfungsi agar isolat triterpenoid dapat larut sempurna dengan aquades. Isolat triterpenoid yang telah dilarutkan dengan $3 \mathrm{ml}$ aquades merupakan ekstrak dengan konsentrasi $10 \%$. Selanjutnya ekstrak $10 \%$ tersebut diencerkan sehingga didapatkan variasi ekstrak 3\%, 5\%, 7\% dan 10\%. Dengan variasi konsentrasi tersebut isolat terpenoid kemudian diuji menggunakan metode difusi cakram terhadap bakteri Eschercia coli dan Staphilococcus aureus. Hasil uji antibakteri dapat dilihat pada gambar berikut ini:

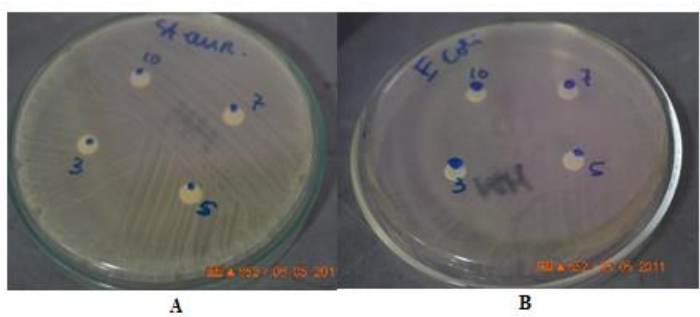

Gambar 9. Hasil uji antibakteri (a) S.aureus dan (b) E.coli

Dari hasil uji aktivitas antibakteri di atas dapat diketahui isolat triterpenoid tidak memiliki aktivitas antibakteri. Hal tersebut dibuktikan tidak adanya zona bening di sekitar cakram. Sehingga dapat disimpulkan bahwa isolat triterpenoid hasil isolasi tidak memiliki aktivitas antibakteri untuk bakteri Eschercia coli dan Staphilococcus aureus. Hal tersebut dapat diakibatkan oleh beberapa faktor diantaranya populasi bakteri uji yang terlalu padat yaitu 1x108 CFU/mL. Faktor lainnya kondisi bakteri yang sudah resisten terhadap senyawa antibakteri.

\section{Kesimpulan}

Hasil penelitian menunjukkan bahwa kitinase dapat diisolasi dari kapang Trichoderma viride FNCC 6013 dengan kitin koloid sebagai induser. Pertumbuhan biomassa sel Trichoderma viride FNCC 6013 dan produksi kitinase mengalami peningkatan dengan adanya penambahan biotin meskipun tidak signifikan. Kondisi pH optimum pada reaksi enzimatik kitinase dari media produksi tanpa penambahan biotin, dengan penambahan biotin sebesar $0,1 \mathrm{mg} / \mathrm{mL}$ dan $0,3 \mathrm{mg} / \mathrm{mL}$ berturut-turut pada pH 3,6; 4,2; dan 4,2. Kondisi suhu optimum pada reaksi enzimatik kitinase dari media produksi tanpa penambahan biotin, dengan penambahan biotin $0,1 \mathrm{mg} / \mathrm{mL}$ dan $0,3 \mathrm{mg} / \mathrm{mL}$ berturutturut pada suhu $27,5^{\circ} \mathrm{C}, 29^{\circ} \mathrm{C}$ dan $29^{\circ} \mathrm{C}$.

\section{Daftar Pustaka}

[1] RE Nasution, S Riswan, P Tjitropranoto, EB Walujo, W Martowikromo, H Roemantyo, SS Wardoyo, Prosiding Seminar dan Loka Karya Nasional Etnobotani, Departement Pendidikan dan Kebudayaan RI-LIPI. Perpustakaan Nasional RI. Jakarta, (1992)

[2] Hembing Wijayakusuma, Tanaman berkhasiat obat di Indonesia, Pustaka Kartini, 1996.

[3] Pedro Aqueveque, Timm Anke, Heidrun Anke, Olov Sterner, José Becerra, Mario Silva, Favolon B, a new triterpenoid isolated from the chilean Mycena sp. 
strain 96180, Journal of Antibiotics, 58, 1, (2005) 61 http://dx.doi.org/10.1038/ja.2005.7

[4] Loisyana, Identifikasi, Inventarisasi Senyawa Triterpenoid dan Uji Brine Shrimp pada Beberapa Tanaman Obat Tradisional Masyarakat Bengkulu, Skripsi, Chemistry, Universitas Bengkulu, Bengkulu

[5] Buyung Rukmantara Susena Putra, Dewi Kusrini, Enny Fachriyah, Isolasi Senyawa Antioksidan dari Fraksi Etil Asetat Daun Tempuyung (Sonchus arvensis L), Jurnal Kimia Sains dan Aplikasi, 16, 3, (2013) 69-72

[6] Tanushree Patnaik, RK Dey, Panchanan Gouda, Isolation of triterpenoid glycoside from bark of Terminalia arjuna using chromatographic technique and investigation of pharmacological behavior upon muscle tissues, Journal of Chemistry, 4, 4, (2007) 474-479 